\title{
Article/Artigo
}

\section{Pulmonary paracoccidoidomycosis: radiology and clinical-epidemiological evaluation}

\author{
Paracoccidioidomicose pulmonar: radiologia e avaliação clínico-epidemiológica
}

\author{
Ricardo Miguel Costa de Freitas ${ }^{1,2}$, Renata Prado ${ }^{3}$, Fábio Luis Silva do Prado ${ }^{4}$, Ivie Braga de Paula ${ }^{5}$, Marco Túlio Alves \\ Figueiredo $^{6}$, Cid Sérgio Ferreira ${ }^{7}$, Eugenio Marcos Andrade Goulart ${ }^{8}$ and Enio Roberto Pietra Pedroso ${ }^{9,10}$
}

\begin{abstract}
Introduction: The purpose of this study was to compare respiratory signs and symptoms between patients with and without chest X-ray abnormalities in order to establish the meaning of radiographic findings in pulmonary PCM diagnosis. Methods: The epidemiological, clinical and radiological lung findings of 44 patients with paracoccidiodomycosis (PCM) were evaluated. Patients were divided into two groups of 23 and 21 individuals according to the presence (group 1) or absence (group 2) of chest X-ray abnormalities, respectively, and their clinical data was analyzed with the aid of statistical tools. Results: As a general rule, patients were rural workers, young adult males and smokers - group 1 and 2, respectively: males (91.3\% and 66.7\%); mean age (44.4 and 27.9 year-old); smoking (34.7\% and $71.4 \%)$; acute/subacute presentation (38.1\% and $21.7 \%)$; chronic presentation (61.9\% and $78.3 \%)$. The most frequent respiratory manifestations were - group 1 and 2, respectively: cough (25\% and $11.4 \%)$ and dyspnea $(22.7 \%$ and $6.8 \%)$. No statistical difference was observed in pulmonary signs and symptoms between patients with or without radiographic abnormalities. The most frequent radiological finding was nodular $(23.8 \%)$ or nodular-fibrous (19\%), bilateral (90.5\%) and diffuse infiltrates (85.7\%). Conclusions: Absence of statistical difference in pulmonary signs and symptoms between these two groups of patients with PCM indicates clinical-radiological dissociation. A simplified classification of radiological lung PCM findings is suggested, based on correlation of these data and current literature review.
\end{abstract}

Key-words: Paracoccidioidomycosis. Epidemiology. Chest X-ray. Classification.

\section{RESUMO}

Introdução: Comparar sinais e sintomas respiratórios entre pacientes com e sem alterações à radiografia de tórax para se estabelecer o significado dos achados radiográficos no diagnóstico da paracoccidioidomicose pulmonar. Métodos: Os achados epidemiológicos, clínicos e radiológicos de 44 pacientes com paracoccidioidomicose (PCM) foram avaliados. Os pacientes foram divididos em dois grupos de 23 e 21 indivíduos de acordo com a presença (grupo 1) ou ausência (grupo 2) de anormalidades à radiografia de tórax, respectivamente, e seus dados clínicos foram analisados com auxílio de ferramentas estatísticas. Resultados: Como regra geral, os pacientes eram trabalhadores rurais do sexo masculino, tabagistas e em idade adulta jovem - grupo 1 e 2, respectivamente: homens (91,3\% e 66,7\%); média de idade (44,4 e 27,9 anos); tabagismo (34,7\% e $71,4 \%)$; forma aguda/subaguda (38,1\% e $21,7 \%)$; forma crônica $(61,9 \%$ e $78,3 \%)$. As manifestações respiratórias mais frequentes foram - grupo 1 e 2, respectivamente: tosse (25\% e $11,4 \%)$ e dispnéia $(22,7 \%$ e $6,8 \%)$. Nenhuma diferença estatística foi observada nos sinais e sintomas respiratórios entre pacientes com ou sem anormalidades radiográficas. Os achados radiológicos mais frequentes foram o padrão nodular (23,8\%) ou nodular-fibrótico (19\%), bilateral (90,5\%) e infiltrado difuso (85,7\%). Conclusões: A ausência de diferença estatística nos sinais e sintomas pulmonares entre estes dois grupos de pacientes com PCM sugere dissociação clínico-radiológica. Uma classificação simplificada dos achados radiológicos pulmonares da PCM é sugerida, com base na correlação destes dados e revisão da literatura atual.

Palavras-chaves: Paracoccidioidomicose. Epidemiologia. Radiografia de tórax. Classificação.

1. Radiology Unit, Sao Paulo Cancer Institute, Sao Paulo, SP, Brazil. 2. Medical School, University of Sao Paulo, Sao Paulo, SP, Brazil. 3. Dermatology Department, Denver and Health Sciences Center, University of Colorado, Aurora, CO, USA. 4. Internal Medicine Department, Sarah Kubitschek Hospital, Salvador, BA, Brazil 5. Radiology Unit, Hermes Pardini Institute, Belo Horizonte, MG, Brazil. 6. Propedeutics Department, Medical School, Federal University of Minas Gerais, Belo Horizonte, MG, Brazil. 7. Radiology Unit, University Hospital, Federal University of Minas Gerais, Belo Horizonte, MG, Brazil. 8. Pediatrics Department, Medical School, Federal University of Minas Gerais Belo Horizonte, MG, Brazil. 9. Internal Medicine Department, Medical School, Federal University of Minas Gerais, Belo Horizonte, MG, Brazil. 10. Tropical Medicine and Infectious Diseases Post-graduation Program, Medical School, Federal University of Minas Gerais, Belo Horizonte, MG, Brazil. Addres to: Dr. Ricardo Miguel Costa de Freitas. Dept ${ }^{\circ}$ Radiologia/ICESP. Av Dr. Arnaldo 251, 01246-000 São Paulo, SP, Brazil.

Tel: 5511 3893-2945

e-mail: ricardomcfreitas@gmail.com

Received in 09/06/2010

Accepted in 16/09/2010

\section{INTRODUCTION}

Paracoccidioidomycosis (PCM), an inflammatory granulomatous systemic disease first reported by Lutz in 1908, is endemic in Latin America and is caused by Paracoccidioides brasiliensis ${ }^{1}$. Mucous and skin lesions are usually common, and lung involvement may be extensive and may cause severe respiratory symptoms. Prolonged asymptomatic periods allow patients to travel far from the endemic areas before development of clinical disease ${ }^{2}$.

Although imaging methods such as high resolution computed tomography or pulmonary scintilography provide more detailed information, conventional chest radiography is still a valuable tool in evaluating PCM lung involvement, especially in countries where costs of more sophisticated imaging methods may be prohibiting ${ }^{3-7}$. Chest X-ray is frequently abnormal in patients with PCM and shows non-specific lung changes. However, the correlation of radiological abnormalities with respiratory symptoms in patients with PCM is not well known ${ }^{8,9}$.

Available radiological classification of PCMinduced chest X-ray abnormalities is heterogeneous in the specific literature $\mathrm{e}^{10-12}$ and sometimes complex, as one based in the Pneumoconiosis Radiography Classification of the International Labor Office (ILO) ${ }^{13}$. This heterogeneity indicates that none of the published radiological classifications is currently universally accepted. A clinically relevant standardized radiological classification of chest X-ray abnormalities in PCM is needed, as it may allow better communication among physicians further our understanding on the prognostic implications of specific findings, and ultimately improve patient care.

To establish the meaning of radiological findings in the pulmonary PCM diagnosis, we compared the clinical symptoms and epidemiologic data of 44 patients with PCM followed in the Federal University of Minas Gerais Clinics Hospital, according to the presence or absence of chest X-ray abnormalities. A review of the current pulmonary PCM radiology literature, as well as its classification, is also presented. 


\section{METHODS}

Medical records and imaging studies from 61 patients with a diagnosis of PCM followed at our University Hospital from 1976 to 2005 were reviewed retrospectively with the approval of our institutional human studies review board (protocol 0082/00). Inclusion criteria were patients who received the diagnosis of PCM and who had a chest X-ray performed at the time of the first consultation. The diagnosis of PCM was performed by direct visualization of the microorganism (in tissue, using histopathology, or in fresh material such as sputum or lymph node aspiration). Exclusion criteria were other lung diseases, such as previous medical history of tuberculosis, asthma, chronic obstructive pulmonary disease (COPD), mining work, exposure to free silica particles and granulomatous diseases such as sarcoidosis. When indicated, major infectious or non-infectious granulomatous diseases were excluded by clinical examination and follow-up with serum, microbiologic or pathological findings. Since a large number of the patients were smokers, patients with proven or suspected chronic obstructive pulmonary disease could not be excluded from the study.

Clinical and epidemiological data were collected from the medical records, with special attention to gender, age, race, education level, occupation, contact with rural areas, presence of weight lost, weakness, fever, sweating, lymph node enlargement, mucosal or skin lesions, dyspnea, cough, expectoration, and chest fremitus, percussion or auscultation abnormalities.

Anterior-posterior and lateral chest radiographies were blindly reviewed by two radiologists (MTAF and CSF) with more than 30 years of experience in thoracic imaging. The radiographies were analyzed according to Magalhães' classification ${ }^{12}$. A third radiologist opinion was taken in three occasions (IBP), when significant divergence between the two firsts was observed. Patients were then divided in two groups, according to the presence or absence of chest X-ray abnormalities. Clinical and demographic data was compared between both groups. Radiological classification analysis was carried out in the group of chest X-ray abnormalities.

Data were collected and analyzed using SPSS for Windows software (8.0.0 version, 1997, Chicago, IL). Statistical analysis was performed with frequency tables, Pearson's chi-square test $\left(X_{2}\right)$ and Yates' correction for continuity $\left(X_{2 C C}\right)$ in $2 \times 2$ tables. A p value less or equal to 0.05 was considered statistically significant. Odds Ratio pointed the direction of association, in case of a representative $X_{2}$ ( $2 \times 2$ tables).

\section{RESULTS}

Sixty-one patients met our inclusion criteria and were selected for this study. Of these, seventeen patients were excluded due to previous tuberculosis (nine patients); asthma (three patients); COPD (two patients); history of mining work (two patients); and exposure to free silica particles (one patient).
PCM diagnosis was made by a positive Gomori-Groccot stain of skin or mucosal biopsies (88.6\%), by direct visualization of the microorganism in $\mathrm{KOH}$ stained sputum $(6.8 \%)$ or lymph node aspiration $(2.3 \%)$, or by a positive Gomori-Groccot stain of liver biopsy (2.3\%).

Epidemiological characteristics, including gender, age, ethnic, education level, and occupation are presented in Table 1. It was observed a predominance of men $(79.5 \%)$ with a mean age of 35.5 years old (age ranged between 12 and 74 years old), with biethnic origin (african-brazilian and caucasian parents, $47.7 \%$ ) and with middle and high school as the predominant highest level of education (50\%). Rural contact was reported by $88.6 \%$ of patients, and $50 \%$ were agriculture workers. They were mainly from State of Minas Gerais (97.7\%), and 50\% from its central region - around Belo Horizonte, the state capital. According to the findings of the initial chest X-ray, patients were divided into two groups: presence of pulmonary radiographic abnormalities associated with PCM

TABLE 1 - Epidemiological data of a group of 44 patients with paracoccidiodomycosis from the southeast region of Brazil.

\begin{tabular}{|c|c|c|c|c|c|c|}
\hline & \multicolumn{2}{|c|}{$\begin{array}{c}\text { Altered chest } \\
\text { X-ray }\end{array}$} & \multicolumn{2}{|c|}{$\begin{array}{c}\text { Normal chest } \\
\text { x-ray }\end{array}$} & \multirow[b]{2}{*}{$\mathrm{X} \neg_{2}$ value } & \multirow[b]{2}{*}{$\mathrm{p}$ value } \\
\hline & $\mathrm{n}$ & $\%$ & $\mathrm{n}$ & $\%$ & & \\
\hline \multicolumn{7}{|l|}{ Gender } \\
\hline male & 21 & 47.7 & 14 & 31.8 & 2.72 & 0.09 \\
\hline female & 2 & 4.5 & 7 & 15.9 & & \\
\hline total & 23 & 100.0 & 21 & 100.0 & & \\
\hline \multicolumn{7}{|l|}{ Age (years old) } \\
\hline $12-18$ & 2 & 4.5 & 7 & 15.9 & 7.69 & 0.02 \\
\hline $19-40$ & 8 & 18.2 & 10 & 22.7 & & \\
\hline $40-74$ & 13 & 29.5 & 4 & 9.1 & & \\
\hline total & 23 & 100.0 & 21 & 100.0 & & \\
\hline \multicolumn{7}{|l|}{ Ethnic group } \\
\hline caucasian & 3 & 6.8 & 3 & 6.8 & 0.025 & 0.99 \\
\hline black & 7 & 15.9 & 6 & 13.6 & & \\
\hline bietnhic (african-brazilian/caucasian) & 11 & 25.0 & 10 & 22.7 & & \\
\hline not mentioned* & 2 & 4.5 & 2 & 4.5 & & \\
\hline total & 23 & 100.0 & 21 & 100.0 & & \\
\hline \multicolumn{7}{|l|}{ School level } \\
\hline illiterate & 2 & 4.5 & 0 & - & 4.12 & 0.25 \\
\hline elementary school & 0 & - & 2 & 4.5 & & \\
\hline middle and junior high school & 7 & 15.9 & 9 & 20.4 & & \\
\hline high school & 3 & 6.8 & 3 & 6.8 & & \\
\hline not mentioned* & 11 & 25.0 & 7 & 15.9 & & \\
\hline total & 23 & 100.0 & 21 & 100.0 & & \\
\hline \multicolumn{7}{|l|}{ Occupation } \\
\hline agriculture worker & 14 & 31.8 & 8 & 18.2 & 5.43 & 0.14 \\
\hline unemployed & 1 & 2.3 & 4 & 9.1 & & \\
\hline student & 0 & - & 2 & 4.5 & & \\
\hline other & 8 & 18.2 & 7 & 15.9 & & \\
\hline total & 23 & 100.0 & 21 & 100.0 & & \\
\hline \multicolumn{7}{|l|}{ Smokers } \\
\hline smokers & 8 & 31.8 & 15 & 18.2 & 4.53 & 0.03 \\
\hline non-smokers & 15 & 2.3 & 6 & 9.1 & & \\
\hline total & 23 & 100.0 & 21 & 100.0 & & \\
\hline
\end{tabular}

*data excluded from chi-square analysis 
(23 patients) or normal thorax X-ray films (21 patients). There were no statistical significant differences in the demographic characteristics between the two groups, except for patient's age (Table 1). Chest X-ray lung abnormalities were significantly more frequent in oldest patients $(\mathrm{p}<0.05)$.

In the group with pulmonary radiographic abnormalities, eight were smokers (34\%), while the group with normal initial chest X-rays had 15 (65\%, $\mathrm{p}<0.03$ ) smokers. General or respiratory signs and symptoms were similar between patients with or without lung radiological abnormalities. Dyspnea and cough were more frequent in patients with chest $\mathrm{X}$-ray abnormalities, but this difference did not reach statistical significance. Comparison of the other signs and symptoms between the two groups also showed no significant statistical difference, a part from lymph node enlargement, more frequent observed in patients with normal chest X-rays (Table 2).

Twenty-six patients presented with respiratory signs and symptoms: one group with chest X-ray abnormalities $(n=16)$ and other group with normal chest X-rays $(n=10)$; eighteen patients had no respiratory signs and symptoms: the group with chest X-ray abnormalities $(\mathrm{n}=7)$ and the other with normal chest X-rays $(\mathrm{n}=11)$; each group had patients with oropharyngeal or upper respiratory tract lesions and no statistical difference between respiratory signs and symptoms and chest X-ray abnormalities was observed (Pearson Chi-square value $=2,187 ; \mathrm{p}<0.139$ ).

Initial clinical presentation is listed in Table 2. Most (70.5\%) patients had chronic multifocal presentation. Half of the patients presented with respiratory symptoms.

The radiographic lung abnormalities of 21 patients are presented in Table 3. Bilateral involvement was seen in $90.5 \%$ of the images, and most patients had abnormal findings affecting more than one third of the lungs $(85.7 \%)$ with no predilection for upper or lower lobes. An isolated radiological lung pattern (nodular, micronodular, fibrous, infiltrative or lung consolidation) was present in $52.2 \%$. Nodular pattern was the most $(23.8 \%)$ frequent, followed by fibrous (9.5\%) and micronodular (9.5\%). A radiological mixed pattern was defined as any simultaneous combination of the above patterns. In these radiographs, it was noted that the nodular pattern was always present, and the combination of nodular and fibrous pattern was the most (19\%) frequent mixed pattern observed. Pneumothorax, cardiomegaly, or bone abnormalities were not observed. The most representative radiographies with PCM lung patterns were presented in Figures 1A and 1B. Two patients with mediastinal enlargement or pleural effusion at chest radiographies were excluded from the radiological analysis, as we aimed to evaluate the specific radiological abnormalities of the lung parenchyma.
TABLE 2 - Most frequent general and respiratory signs and symptoms and initial clinical presentation of a group of $\mathbf{4 4}$ patients with paracoccidiodomycosis coming from the southeast region of Brazil.

\begin{tabular}{|c|c|c|c|c|c|c|}
\hline \multirow[b]{2}{*}{ Signs and symptoms } & \multicolumn{2}{|c|}{$\begin{array}{c}\text { Altered chest } \\
\text { x-ray }\end{array}$} & \multicolumn{2}{|c|}{$\begin{array}{c}\text { Normal chest } \\
\text { x-ray }\end{array}$} & \multirow[b]{2}{*}{$\mathrm{X} \neg_{2}$ value } & \multirow[b]{2}{*}{$\mathrm{p}$ value } \\
\hline & $\mathrm{n}$ & $\%$ & $\mathrm{n}$ & $\%$ & & \\
\hline \multicolumn{7}{|l|}{ General } \\
\hline weight loss & 17 & 38.6 & 13 & 29.5 & 0.73 & 0.39 \\
\hline lymph node enlargement & 11 & 25.0 & 17 & 38.6 & 5.20 & 0.02 \\
\hline weakness & 14 & 31.8 & 10 & 22.7 & 0.77 & 0.37 \\
\hline fever & 8 & 18.2 & 12 & 27.3 & 2.21 & 0.13 \\
\hline pallor & 9 & 20.4 & 8 & 18.2 & 0.005 & 0.94 \\
\hline mucosal lesions & 14 & 31.8 & 10 & 22.7 & 0.77 & 0.38 \\
\hline skin lesions & 6 & 13.6 & 9 & 20.4 & 1.37 & 0.24 \\
\hline Sweating & 5 & 11.4 & 2 & 4.5 & 0.48 & 0.48 \\
\hline dizziness & 4 & 9.1 & 3 & 6.8 & 0.08 & 0.77 \\
\hline dysphonia & 2 & 4.5 & 4 & 9.1 & 0.99 & 0.32 \\
\hline hoarseness & 4 & 9.1 & 2 & 4.5 & 0.57 & 0.45 \\
\hline nasal obstruction & 1 & 2.3 & 3 & 6.8 & 1.31 & 0.25 \\
\hline lower extremity edema & 1 & 2.3 & 2 & 4.5 & 0.46 & 0.49 \\
\hline \multicolumn{7}{|l|}{ Respiratory } \\
\hline cough & 11 & 25.0 & 5 & 11.4 & 1.79 & 0.18 \\
\hline expectoration/productive cough & 11 & 25.0 & 4 & 9.1 & 2.86 & 0.09 \\
\hline dyspnea & 10 & 22.7 & 3 & 6.8 & 3.20 & 0.07 \\
\hline rales & 5 & 11.4 & 2 & 4.5 & 0.48 & 0.4 \\
\hline abnormal fremitus & 4 & 9.1 & 1 & 2.3 & 0.71 & 0.39 \\
\hline thorax deformity & 3 & 6.8 & 2 & 4.5 & 0.00 & 1.00 \\
\hline limited thoracic expansibility & 3 & 6.8 & 1 & 2.3 & 0.18 & 0.66 \\
\hline pleural friction rub & 2 & 4.5 & 0 & - & 1.91 & 0.16 \\
\hline wheezes & 2 & 4.5 & 0 & - & 1.91 & 0.16 \\
\hline abnormal thorax percussion & 1 & 2.3 & 0 & - & 0.93 & 0.33 \\
\hline
\end{tabular}

\begin{tabular}{lrrrr}
\hline Clinical presentation & & & & \\
acute/subacute & 8 & 38.1 & 5 & 21.7 \\
chronic (unifocal) & 5 & 23.8 & 0 & - \\
chronic (multifocal) & 8 & 38.1 & 18 & 78.3 \\
\hline Total & $\mathbf{2 1}$ & $\mathbf{1 0 0 . 0}$ & $\mathbf{2 3}$ & $\mathbf{1 0 0 . 0}$
\end{tabular}
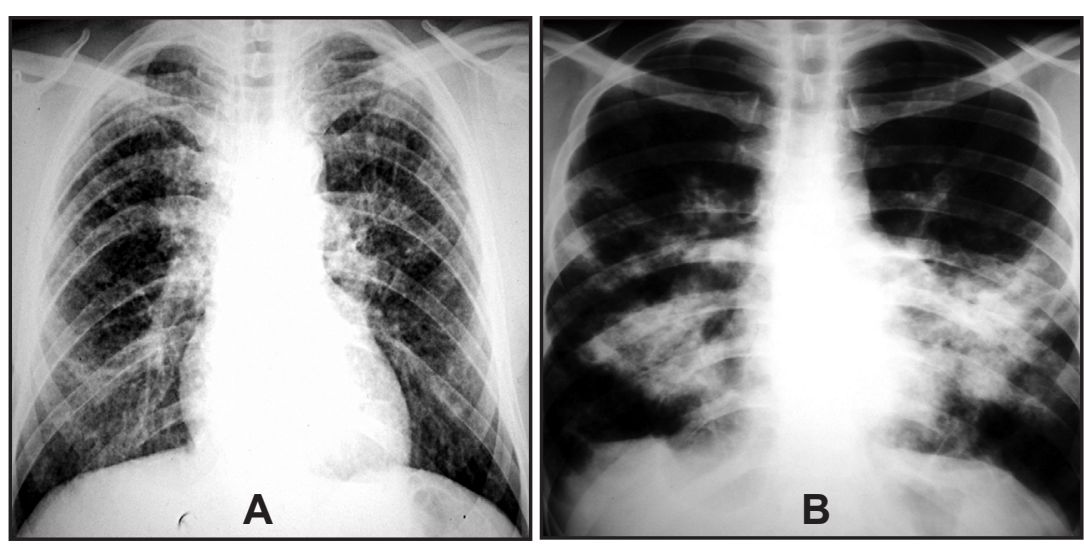

FIGURE 1 - A) Postero-anterior chest $x$-ray. Case \#2, male, 49 year-old: reticular-nodular pattern. B) Postero-anterior chest X-ray. Case \# 10, male, 36 year-old: lung consolidation pattern. 
TABLE 3 - General chest X-ray abnormalities and lung opacities patterns of 21 patients with paracoccidiodomycosis in a group of 44 patients coming from the southeast region of Brazil.

\begin{tabular}{lcc}
\hline Abnormality & Number & Percentage \\
\hline Distribution & 2 & \\
$\quad$ unilateral & 19 & 9.5 \\
bilateral & & \\
\hline Extension & 3 & 14.3 \\
$\leq 1 / 3$ of lung area & 18 & 85.7 \\
$>1 / 3$ of lung area & & \\
\hline
\end{tabular}

\begin{tabular}{lrr}
\hline Localization & & \\
upper, middle and basal zones & 10 & 47.6 \\
upper and middle zones & 6 & 28.5 \\
middle and basal zones & 2 & 9.5 \\
basal zones alone & 2 & 9.5 \\
middle zones alone & 1 & 4.7 \\
upper zones alone & 0 & 0.0 \\
\hline Isolated pattern & & \\
nodular & 5 & 23.8 \\
fibrous & 2 & 9.5 \\
micro-nodular & 2 & 9.5 \\
infiltrative & 1 & 4.7 \\
lung consolidation & 1 & 4.7 \\
Sub-total & 11 & 52.2 \\
\hline
\end{tabular}

\section{Mixed pattern}

\begin{tabular}{lcc} 
nodular-fibrous & 4 & 19.0 \\
nodular-infiltrative & 2 & 9.5 \\
nodular-micro-nodular & 1 & 4.7 \\
nodular-lung consolidation & 1 & 4.7 \\
nodular-lung consolidation-fibrous & 1 & 4.7 \\
nodular-fibrous-cavity & 1 & 4.7 \\
Sub-total & 10 & 47.8 \\
\hline Total & $\mathbf{2 1}$ & $\mathbf{1 0 0 . 0}$ \\
\hline
\end{tabular}

\section{DISCUSSION}

PCM, formerly known as South-American blastomycosis, is a specific endemic entity in Latin America. As a chronic systemic mycosis it carries a high morbidity and mortality, especially in cases of diffuse systemic involvement ${ }^{14}$ or when associated with immune compromising conditions $s^{15-17}$, as also noticed with other endemic fungal diseases ${ }^{18-20}$. The prevalence of PCM in Brazil is estimated by regional serological surveys or epidemiological mortality reviews ${ }^{2,21-23}$. PCM was the $8^{\text {th }}$ cause of mortality by chronic infectious diseases in Brazil, causing 3,181 deaths between 1980 and 1995. Agriculture and civil construction workers represented $55.8 \%$ and $19.2 \%$ of deaths by PCM, respectively ${ }^{21}$.

In our study, patients with PCM were predominantly young adult men, agriculture workers in the economically active population, and/or with previous contact to rural areas - which is similar to the epidemiologic data found in the literature ${ }^{2,8,9,11,13,21,22,24-27}$. Interestingly, our male to female ratio was 3.9:1, and it has varied from 5.4-10:1 in other studies ${ }^{8,22}$. As PCM literature is updated, women prevalence rises as their work prevalence increases in rural or urban regions ${ }^{28}$, as well as their increasing participation in the smokers population ${ }^{29}$. Women's protection by hormonal or genetic factors ${ }^{30}$ may actually be less important than previously thought.
The low education level and the biethnic origin predominance of our patients is data not previously well explored ${ }^{8,9,13,22,24,26,27}$ and it agrees with the consensus that PCM has an occupational character, being more frequent in the rural and poor Brazilian population. Southeast, south and mid-west Brazil regions aggregate the majority of patients, although new cases have been reported in the past years in forest frontiers, such as in the Amazon region, infecting Indians and immigrants (e.g. mining or agriculture workers ${ }^{21}$. With increasing international traveling, people from non-endemic countries may become exposed to this yeast, rendering this disease an entity to be promptly recognized and included as a differential diagnosis in many clinical situations.

Chest X-ray lung abnormalities were significantly more frequent in oldest patients $(\mathrm{p}<0.05)$, which correlates with the increase of pulmonary abnormalities found in the chronic presentation of the disease (Table 1). However, the impact of duration of smoking in the radiographic alterations was not evaluated in this study, and cannot be excluded. In our study, $52.3 \%$ of patients were smokers, but only the minority of these patients $(34.7 \%)$ had radiographic lung abnormalities. Smoking is a significant intervenient variable among PCM patients, with a prevalence of $65.5 \%$ to $90.3 \%$ in the literature ${ }^{8,13,26}$. In a case control study by Santos et al, smoking was found to be an important risk factor to the development of chronic PCM. The number of cigarettes smoked per day was also found to be inversely correlated with the age of the patient at the disease onset ${ }^{29}$. However, a comparative study of chest X-ray abnormalities between smokers and no smokers with pulmonary PCM has not yet been performed.

The most common general signs and symptoms found in our study were weight loss, lymph node enlargement, mucous lesions, weakness, and fever. Cough, expectoration and dyspnea were the most common reported respiratory symptoms, which is consistent with the literature ${ }^{8,11,13,22,27}$. Our study demonstrates that respiratory symptoms were similar in patients with or without chest X-ray abnormalities, indicating a clinical-radiological dissociation. Lymph node enlargement was more frequently seen in patients with normal chest $\mathrm{x}$-rays $(\mathrm{p}<0.05)$, and this was probably due to clinical presentations (Table 2), where lymph node involvement was observed in $59.1 \%$ of all patients from this study but only $11.4 \%$ had associated pulmonary PCM; otherwise the mucocutaneous presentation associated with lymph node enlargement was observed in $36.3 \%$. Although pulmonary PCM has been exhaustively studied in other Brazilian regions, very little is known about the correlation between respiratory symptoms and radiographic abnormalities in patients with this disease. Gomes et al reports clinical radiological dissociation in a study with 40 patients, although the data presented suggests a trend towards an association with respiratory symptoms and more severe radiologic abnormalities in the chest X-ray ${ }^{31}$. However, as in our study, the limited number of patients, as well as other intervening factors such as smoking, limits more definitive conclusions. Despite the difficulties to study patients with PCM in which all intervening variables are excluded, our results are in agreement with the trend found in the current literature and published studies, and indicate the presence of a clinical radiological dissociation in the chest x-ray of patients with PCM. We are currently conducting studies using more sensitive techniques to further investigate the effects of PCM in the lung.

Since the 1950's, the lung is known to be the most frequently involved viscera in PCM, and the respiratory system the primary mode of spread of the disease ${ }^{32}$. Our data showed that chest X-ray 
abnormalities, when present, were bilateral in $90.5 \%$ and involved more than one third of the lungs (85.7\%), similarly to the current literature ${ }^{10,11,13}$. The pulmonary radiological findings of PCM have been extensively explored in previous studies. Formerly, the pattern miliary grouped was thought to be predominant ${ }^{10}$. In 1966, Ferreira ${ }^{11}$ presented the following classification and the frequency of lesions: predominant nodular pattern $(48.2 \%)$; exclusive miliary pattern (22.2\%); predominant miliary pattern (14.8\%); predominant reticular pattern $(11.1 \%)$ and bronchopneumonic pattern $(3.7 \%)^{11}$. Many other studies have reported predominance of interstitial opacities, but in a heterogeneous fashion. Martins et $\mathrm{al}^{27}$ reported a high percentage of consolidated lesions (30\%), mixed patterns (21.5\%), as well as cavity lesions $(27.2 \%)$ in a series of 121 patients with PCM chest X-ray abnormalities. This data was not well correlated with the literature, likely because patients with previous or concomitant tuberculosis were not excluded ${ }^{27}$. A review of 170 cases of chest $x$-ray abnormalities due to PCM and interpreted with the aid of specific classification ${ }^{12,33}$, showed reticular (26\%) and reticular-nodular (23\%) patterns, followed by reticular-nodular-cavity pattern (13\%), to be the more common radiologic lung patterns, although chest $\mathrm{x}$-ray films choice criteria included the most significant presentations in any moment of the disease $^{25}$. Results from analysis of 64 chest $x$-rays of patients with only extra-respiratory PCM signs and symptoms were briefly reported in another study: confluent or non-confluent alveolar active opacities (25\%), interstitial opacities fibrosis or pleural pulmonary adherences suggesting chronic lesions (40.6\%), or both $(23.4 \%)^{34}$. More recently, an analysis of 270 chest x-ray films of PCM patients showed interstitial opacities and mixed patterns, mainly observed in chronic presentations instead of in acute or sub-acute forms. No information concerning if they were taken at the first consultation was available ${ }^{8}$.

Two studies involving chest $\mathrm{x}$-ray analysis of 173 and 139 patients with $\mathrm{PCM}^{9,35}$ showed predominance of interstitial opacities, but with different incidence in the pneumonic-interstitial bat wings mixed pattern (50\% and $16.6 \%$, respectively) as well as in the fibrous pattern ( $18.2 \%$ and $5 \%$, respectively).

The classification of chest x-ray PCM abnormalities based upon ILO's Pneumoconiosis Standards showed an interstitial pattern predominance (50\%), followed by a reticular-nodular pattern (39.6\%); alveolar pattern (13.7\%); and the mixed pattern (interstitial and alveolar) in $29.3 \%^{13}$. ILO's methodology may not be a prompt useful tool to the internist although the final result is a convergence of abnormalities into three great patterns (interstitial, alveolar and mixed patterns).

It is recommended that the initial diagnostic analysis of PCM should include anterior-posterior and lateral chest $\mathrm{x}$-ray films, and the exam should be repeated during follow up of PCM patients under medical treatment ${ }^{36}$. Although there are many different methodological reports as previously mentioned, thoracic PCM radiography abnormalities are in general bilateral, symmetric, with a nodular-interstitial pattern ${ }^{34,35}$. PCM chest radiography classification, as the one used in our study ${ }^{12}$ is morphologically elucidative. However it is not known if this classification provides the clinician information regarding disease severity or prognosis. Our statistic results show a trend towards independency between chest x-ray findings and clinical disease presentation. Extensively detailed and complex radiographic PCM lung classification plays, therefore, a limited role in the clinical setting, as long as other differential diagnosis such as tuberculosis, are excluded. In this setting, we propose to limit chest x-ray reports to alveolar, interstitial or mixed patterns, when approaching PCM patients, initially and under antimicrobial therapy follow up. A simpler radiographic description may facilitate communication between radiologist and internists, and may allow comparison between studies.

The classification of chest $\mathrm{x}$-ray film abnormalities in PCM patients remains very important whenever the differential diagnosis is required, since tuberculosis and PCM are frequently polymorphic at thoracic imaging. Most importantly, it is essential to recognize that PCM is a disease that can cause a large variety of pulmonary radiographic alterations, and should be included in the differential diagnosis of patients with history of exposure to endemic areas.

Several factors limit our study. The real profile of PCM in State of Minas Gerais must not be concluded from our data, as milder forms of the disease are often followed in the primary care centers. The limited number of patients in our study does not allow us to make definitive statistical conclusions, but shows a trend towards clinical-radiological dissociation. Further studies would be required to confirm this hypothesis. Smoking is still a significant intervenient variable. Currently, little is known about anatomopathological and radiological correlation in PCM, and such studies are needed to increase our knowledge on the pathophysiology of this disease, as well as on its radiological expression in different moments of the inflammatory process.

Clinical, epidemiological and chest $\mathrm{x}$-rays records from 44 adult patients with PCM from State of Minas Gerais, Brazil, were presented. Nodular-interstitial, bilateral and diffuse lung infiltrate was the main chest $\mathrm{x}$-ray abnormalities in chronic PCM. This is the first report of a non-parametric statistical analysis indicating a trend towards independency between respiratory PCM manifestations when compared two groups of patients with or without radiographic lung abnormalities. Since it is yet unknown the relation of initial different morphologic chest $x$-ray patterns and differences in outcome of patients with PCM after treatment, a simplified PCM chest x-ray pattern classification reporting alveolar, interstitial or mixed lung abnormalities is proposed as a result, in order to allow a practical initial approach and follow up of these patients by the internist. Further studies evaluating initial radiological findings with mortality, cure rate and post treatment lung functional capacity would be desirable and clinically relevant.

\section{ACKNOWLEDGMENTS}

We thank Professor Giovanni Guido Cerri for reviewing this manuscript and Tropical medicine and Infectious diseases postgraduation program from Federal University of Minas Gerais by institutional support.

\section{CONFLICT OF INTEREST}

The authors declare that there is no conflict of interest.

\section{FINANCIAL SUPPORT}

Fundação de Amparo à Pesquisa do Estado de Minas Gerais.

\section{REFERENCES}

1. Lutz A. Uma mycose pseudococcidica localisada na bocca e observada no Brasil. Contribuição ao conhecimento das hyphoblastomycoses americanas. Brasil Medico 1908; 22 :121-124; 141-144. 
2. Martinez R. Blastomicose sul-americana (Paracoccicioidomicose). Etioepidemiologia e ecologia. In: Veronesi R, Focaccia R, editors. Tratado de Infectologia. Rio de Janeiro: Atheneu; 1997. p. 1081-1083.

3. Funari M, Kavakama J, Shikanai-Yasuda MA, Castro LG, Bernard G, Rocha MS, et al. Chronic pulmonary paracoccidioidomycosis (south american blastomycosis): highresolution CT findings in 41 patients. AJR Am J Roentgenol 1999; 173:59-64.

4. Teixeira ABMJ, Etchebehere ECSC, Lima MCL, Santos, MCL, Pires, AO, Valença Junior BC, et al. Gallium-67 imaging in a patient with paracoccidioidomycosis: a case report. Rev Inst Med Trop São Paulo 2000; 42:167-170.

5. Achenbach R, Negroni R, Khaski S, Lococo L, Beresñak A, Gai L. Paracoccidioidomycosis: unusual clinical presentation and utility of computerized tomography scanning for diagnosis. Int J Dermatol 2002; 41:881-882.

6. Muniz MAS, Marchiori E, Magnago M, Moreira LBM, Almeida Junior JG. Paracoccidioidomicose pulmonar: aspectos na tomografia computadorizada de alta resolução. Radiol Bras 2002; 35:147-154.

7. Gasparetto EL, Escuissato DL, Davaus T, Cerqueira EMFP, Souza Junior AS Marchiori E, et al. Reversed halo sign in pulmonary paracoccidioidomycosis. AJR Am J Roentgenol 2005; 184:1932-1934.

8. Paniago AMM, AguiarJIA, Aguiar ES, Cunha RV, Pereira GROL, Londero AT, et al. Paracoccidioidomicose: estudo clínico e epidemiológico de 422 casos observados no Estado de Mato Grosso do Sul. Rev Soc Bras Med Trop 2003; 36:455-459.

9. Trad HS, Trad CS, Elias Jr J, Muglia VF. Revisão radiológica de 173 casos consecutivos de paracoccidioidomicose. Radiol Bras 2006; 39:175-179.

10. Gonçalves AP, Bardy C. Aspectos clínicos e radiológicos da blastomicose brasileira pulmonar. O Hospital 1946; 20:213-243.

11. Ferreira LC. O comprometimento pulmonar na blastomicose sul-americana. Arq Bras Tuberc Doenç Torax 1966; 25:41-60.

12. Magalhães A. Paracoccidioidomicose (blastomicose sul-americana), aspectos radiológicos. Rev Hosp Clin Fac Med Sao Paulo 1980; 35:147-155.

13. Leme LM. Aspectos radiológicos da paracoccidioidomicose pulmonar Rev Pat Trop 1989; 18:219-298.

14. Prado FLS, Prado RS, Gontijo CCV, Freitas R, Pereira M, Paula I, et al. Lymphoabdominal paracoccidioidomycosis simulating primary neoplasia of the biliary tract. Mycopathol 2005; 160:25-28.

15. Reis M, Costa RS, Ferraz AS. Causes of death in renal transplant recipients: a study of 102 autopsies from 1968 to 1991. J Royal Soc Med 1995; 88:24-27.

16. Silletti RP, Glezerov V, Schwartz IS. Pulmonary paracoccidioidomycosis misdiagnosed as Pneumocystis pneumonia in an immunocompromised host. J Clin Microbiol 1996; 34:2328-2330.

17. Godoy P, Lelis SSR, Resende UM. Paracoccidioidomicose e síndrome da imunodeficiência adquirida: relato de necropsia. Rev Soc Bras Med Trop 2006; 39:79-81.

18. Boyars MC, Zwischenberger JB, Cox Jr CS. Clinical manifestations of pulmonary fungal infections. J Thorac Imaging 1992; 7:12-22.

19. Winer-Muram HT, Rubin SA. Pulmonary blastomycosis. J Thorac Imaging $1992 ; 7: 23-28$

20. Conces Jr. DJ. Endemic fungal pneumonia in immunocompromised patients. J Thorac Imaging 1999; 14:1-8.

21. Coutinho ZF, Silva D, Lazéra M, Marcia PV, Oliveira RM, Sabroza PC, et al. Paracoccidioidomycosis mortality in Brazil (1980-1995). Cad Saude Publica 2002; 18:1441-1454

22. Blotta MHSL, Mamoni RL, Oliveira SJ, Nouer SA, Papaiordanou PM, Gouveia A, et al. Endemic regions of paracoccidioidomycosis in Brazil: a clinical and epidemiologic study of 584 cases in the southeast region. Am J Trop Med Hyg 1999; 61:390-394.

23. Maluf MLF, Pereira SRC, Takahashi G, Svidzinski TIE. Prevalência de paracoccidioidomicose-infecção determinada através de teste sorológico em doadores de sangue na região Noroeste do Paraná, Brasil. Rev Soc Bras Med Trop 2003; 36:11-16.

24. AzevedoJF, Lisboa CSG. Paracoccidioidomicose - estudo de 106 casos.J Pneumol $1980 ; 6: 30-33$

25. Cruz MFA, Santos Filho RA, Cardoso RC, Prando A, Pereira RM. Aspectos radiográficos intratorácicos da paracoccidioidomicose. Revisão de 170 casos. Radiol bras 1989; 22:169-177.
26. Verli FD, Marinho SA, Souza SC, Figueiredo MAS, Yurgel LS. Perfil clínicoepidemiológico dos pacientes portadores de paracoccidioidomicose no Serviço de Estomatologia do Hospital São Lucas da Pontifícia Universidade Católica do Rio Grande do Sul. Rev Soc Bras Med Trop 2005; 38:234-237.

27. Martins S, Gerhardt Filho G, Monteiro DJ. Aspectos clínicos e radiológicos da paracoccidioidomicose. JBM. 1984; 46:71-79.

28. Instituto Brasileiro de Geografia e Estatística. [database online]. Pesquisa Nacional de Amostra em Domicílios. Rio de Janeiro 2005. 26:1-125.

29. Santos WA, Silva BM, Passos ED, Zandonade E, Falqueto A. Associação entre tabagismo e paracoccidioidomicose: um estudo de caso-controle no Estado do Espírito Santo, Brasil. Cad Saude Publica 2003; 19:245-253.

30. Aristizabal BH, Klemons KV, Cock AM, Restrepo A, Stevens DA. Paracoccidioides brasiliensis infection in mice: influence of the hormonal status of the host on tissue responses. Med Mycol 2002; 40:162-178.

31. Gomes E, Wingeter MA, Svidzinski TIE. Dissociação clínico-radiológica nas manifestações pulmonares da paracoccidioidomicose. Rev Soc Bras Med Trop 2008; 41:454-458.

32. Ferreira MS. Blastomicose sul-americana (paracoccicioidomicose) Imunopatogênese. In: Veronesi R, Focaccia R, editores. Tratado de Infectologia. Rio de Janeiro: Atheneu; 1997. p. 1083-1087.

33. Machado Filho J, Miranda JL. Considerações relativas à blastomicose sulamericana: localizações, sintomas iniciais, vias de penetração e disseminação em 313 casos consecutivos. O Hospital 1960; 58:129-181.

34. Correa AL, Restrepo A, Franco L, Gomez I. Paracoccidioidomicosis: coexistencia de lesiones extrapulmonares y patología pulmonar silente: descripción de 64 pacientes. Acta Med Colomb 1991; 16:304-308.

35. Valle ACF, Guimarães RR, Lopes DJ, Capone D. Aspectos radiológicos torácicos na paracoccidioidomicose. Rev Inst Med Trop São Paulo 1992; 34:107-115.

36. Shikanai-Yassuda MA, Telles Filho FQ, Mendes RP, Colombo AL, Moretti ML, Grupo de Consultores do Consenso em Paracoccidioidomicos. Consenso em paracoccidioidomicose. Rev Soc Bras Med Trop 2006; 39:297-310. 